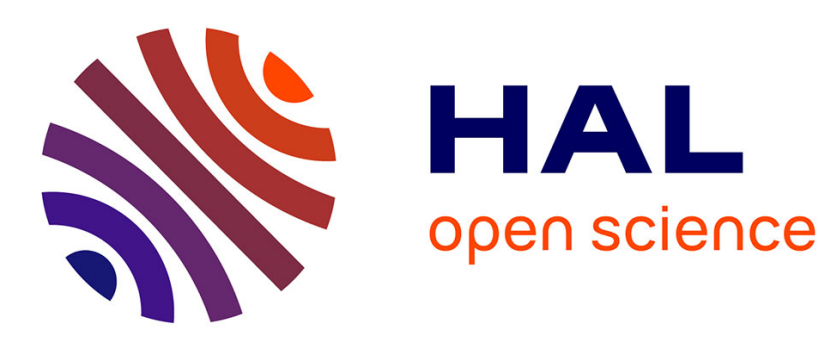

\title{
Unexpected De-Arylation of a Pentaaryl Fullerene
}

Simon Clavaguera, Yves Rubin

\section{To cite this version:}

Simon Clavaguera, Yves Rubin. Unexpected De-Arylation of a Pentaaryl Fullerene. Organic Letters, 2009, 11 (6), pp.1389-1391. 10.1021/ol900224w . cea-01344098

\section{HAL Id: cea-01344098 https://hal-cea.archives-ouvertes.fr/cea-01344098}

Submitted on 11 Jul 2016

HAL is a multi-disciplinary open access archive for the deposit and dissemination of scientific research documents, whether they are published or not. The documents may come from teaching and research institutions in France or abroad, or from public or private research centers.
L'archive ouverte pluridisciplinaire HAL, est destinée au dépôt et à la diffusion de documents scientifiques de niveau recherche, publiés ou non, émanant des établissements d'enseignement et de recherche français ou étrangers, des laboratoires publics ou privés. 


\title{
Unexpected De-Arylation of a Pentaaryl Fullerene
}

\author{
Simon Clavaguera, Saeed I. Khan, and Yves Rubin* \\ Department of Chemistry and Biochemistry, University of California, Los Angeles, \\ California 90095-1569
}

rubin@chem.ucla.edu

Received February 2, 2009

\section{ABSTRACT}
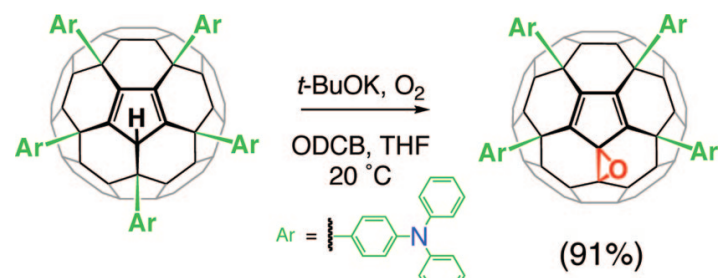

A triphenylamine-derived pentaaryl fullerene undergoes an unusual oxidative dearylation under basic conditions to give tetraarylated epoxy fullerene in high yield. The structure of the product was confirmed by single crystal X-ray diffraction. A mechanism is proposed to account for the loss of the addend and the subsequent formation of the epoxide group.

We have been studying novel approaches to promote greater control over the morphology of the bicontinuous conducting polymer-fullerene network in bulk heterojunction photovoltaic devices. ${ }^{1}$ In the course of our syntheses of a series of pentaarylated fullerene derivatives (shuttlecocks) inspired from Nakamura's work, ${ }^{2}$ we encountered the unexpected dearylation reaction of pentaadduct 1 bearing five triphenylamine addends, which afforded epoxy tetraaryl fullerene $\mathbf{2}$. While this tetraadduct epoxide pattern is commonly encountered in secondary amine and peroxide additions to $\mathrm{C}_{60}$, 3,4 this is the first time that such an adduct is formed by oxidative loss of one addend from a pentaadduct. ${ }^{5}$

(1) Kennedy, R. D.; Ayzner, A. L.; Wanger, D. D.; Day, C. T; Halim, M.; Khan, S. I.; Tolbert, S.; Schwarz, B.; Rubin, Y. J. Am. Chem. Soc. 2008, 130, 17290-17292.

(2) Sawamura, M.; Kawai, K.; Matsuo, Y.; Kanie, K.; Kato, T.; Nakamura, E. Nature 2002, 419, 702-705.

(3) (a) Isobe, H.; Nakanishi, W.; Tomita, N.; Jinno, S.; Okayama, H.; Nakamura, E Chem.-Asian. J. 2006, 1-2, 167-175. (b) Isobe, H.; Tanaka, T.; Nakanishi, W.; Lemiègre, L.; Nakamura, E. J. Org. Chem. 2005, 70, 4826-4832. (c) Isobe, H.; Tomita, N.; Nakamura, Org. Lett. 2000, 2, $3663-$ 3665. (d) Lemiègre, L.; Tanaka, T.; Nanao, T.; Isobe, H.; Nakamura, E. Chem. Lett. 2007, 36, 20-21.

(4) (a) Jia, Z.; Zhang, X.; Zhang, G.; Huang, S.; Fang, H.; Hu, X.; Li, Y.; Gan, L.; Zhang, S.; Zhu, D Chem.-Asian J. 2007, 2, 290-300. (b) Hu, X.; Jiang, Z.; Jia, Z.; Huang, S.; Yang, X.; Li, Y.; Gan, L.; Zhang, S.; Zhu, D. Chem.-Eur. J. 2007, 13, 1129-1141.
Pentafunctionalized fullerenes are interesting targets because their molecular structure (badminton shuttlecockshaped) can promote self-assembly into one-dimensional stacks. ${ }^{1,6}$ They are formed by the highly regioselective and efficient addition of organocopper reagents, prepared by transmetalation between a Grignard reagent and $\mathrm{CuBr} \cdot \mathrm{SMe}_{2}$, to the fullerene $\mathrm{C}_{60}$. Additionally, electron-donating aromatic addends such as triphenylamine (TPA) have been widely used in molecular dyads and triads involving $\mathrm{C}_{60}$ to form light energy harvesting systems or molecular electronic devices. $^{7,8}$

The initial goal of this work was to investigate the influence of a hole transport molecule on the photovoltaic properties of a pentafunctionalized fullerene. It has been

(5) For a recent study of a related phenylcarbazole adduct, see: (a) Zhang, X.; Matsuo, Y.; Nakamura, E. Org. Lett. 2008, 10, 4145-4147.

(6) Matsuo, Y.; Nakamura, E. Chem. Rev. 2008, 108, 3016-3028.

(7) (a) Williams, R. M.; Zwier, J. M.; Verhoeven, J. W. J. Am. Chem. Soc. 1995, 117, 4093-4099. (b) Martin, N.; Sanchez, L.; Illescas, B.; Perez, I. Chem. Rev. 1998, 98, 2527-2548.

(8) (a) Komamine, S.; Fujitsuka, M.; Ito, O.; Moriwaki, K.; Miyata, T.; Ohno, T. J. Phys. Chem A. 2000, 104, 11497-11504. (b) Han, Y.; Dobeck, L.; Gong, A.; Meng, F.; Spangler, C. W.; Spangler, L. H. Chem. Commun. 2005, 1067-1069. (c) Zeng, H. P.; Wang, T.; Sandanayaka, A. S. D.; Araki, Y.; Ito, O. J. Phys. Chem. A 2005, 109, 4713-4720. (d) El-Khouly, M. E.; Kim, J. H.; Kwak, M.; Choi, C. S.; Ito, O.; Kay, K-Y. Bull. Chem. Soc. Jpn. 2007, 80, 2465-2472. 
Scheme 1. Synthesis of Pentaadduct 1 and Subsequent De-Arylation Providing Tetraadduct Epoxide 2
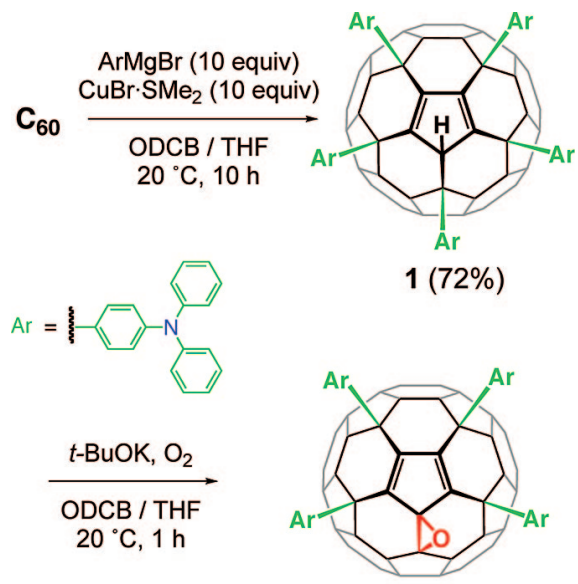

$2(91 \%)$ shown that the addition of small hole-transporting molecules, like TPA, to bulk heterojunction solar cells based on conjugated polymers and fullerenes results in an increased power conversion efficiency. ${ }^{9}$

Compound 1 was prepared by Grignard reagent formation from 4-bromo-N,N-diphenylaniline, which was transmetalated in situ with $\mathrm{CuBr} \cdot \mathrm{SMe}_{2}$ and added to $\mathrm{C}_{60}$ (Scheme 1). For this particular reaction, the quenching step is critical and has to be performed with degassed solutions under argon. We observed an unusually facile tendency for $\mathbf{1}$ to convert to epoxide $\mathbf{2}$ during the workup process if the quenchings were not rigorously done under inert atmosphere.

In a controlled synthesis of epoxide $\mathbf{2}$, deprotonation of the cyclopentadiene hydrogen of compound $\mathbf{1}$ with potassium tert-butoxide resulted in a color change of the reaction mixture from red orange to dark-red for the corresponding anion. Reaction with $\mathrm{O}_{2}$ in the absence of light gave the $C_{\mathrm{s}^{-}}$ symmetric epoxide 2 as a single product in $91 \%$ yield after purification on silica gel $\left(\mathrm{CS}_{2} / \mathrm{CH}_{2} \mathrm{Cl}_{2}\right.$ 9:1). The oxidation of 1 cleanly gives epoxy[60]fullerene 2 , without benzo[b]furan products nor polyoxygenated derivatives, unlike the exposure of $\mathrm{C}_{60} \mathrm{Ph}_{5} \mathrm{Cl}, \mathrm{C}_{60} \mathrm{Ph}_{5} \mathrm{H}$, or the corresponding $p$ fluorophenyl derivative to air. ${ }^{10,11}$ Additional epoxidation of a double bond in the central cyclopentadiene unit can also lead to several polyoxygenated products. The propensity of the cyclopentadiene system to oxidize is illustrated with the $\mathrm{X}$-ray crystal structure of $C_{\mathrm{s}}$-symmetric bisepoxyfullerene $\mathrm{C}_{60} \mathrm{Me}_{5} \mathrm{O}_{2} \mathrm{OH}$, which was produced in the reaction of $\mathrm{C}_{60} \mathrm{Cl}_{6}$

(9) (a) Yang, C. H.; Qiao, J.; Sun, Q. J.; Jiang, K. J.; Li, Y. L.; Li, Y. F. Synth. Met. 2003, 137, 1521-1522. (b) Hendrickx, E.; Kippelen, B.; Thayumanavan, S.; Marder, S. R.; Persoons, A.; Peyghambarian, N. J. Chem. Phys. 2000, 112, 9557-9561.

(10) (a) Darwish, A. D.; Avent, A. G.; Birkett, P. R.; Kroto, H. W.; Taylor, R.; Walton, D. R. M. J. Chem. Soc., Perkin Trans. 2 2001, 10381044. (b) Avent, A. G.; Birkett, P. R.; Darwish, A. D.; Kroto, H. W.; Taylor, R.; Walton, D. R. M. Chem. Commun. 1997, 1579-1580.

(11) For a nonepoxidized fulvene-type tetrakisadduct, see: (a) Murata, Y.; Shiro, M.; Komatsu, K. J. Am. Chem. Soc. 1997, 119, 8117-8118.

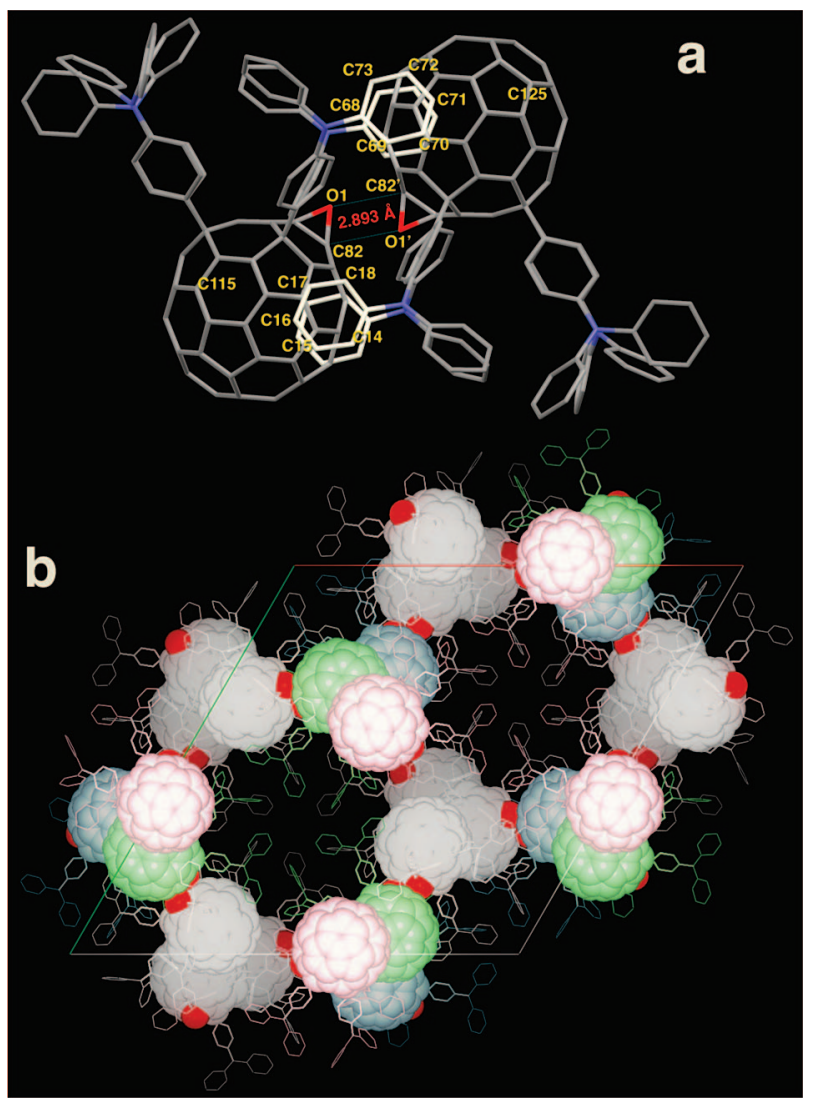

Figure 1. (a) X-ray structure of $\mathbf{2}$ showing dimeric pairs with tight $\mathrm{C} \cdots \mathrm{O}$ contacts. Hydrogen and included solvent are omitted. (b) Packing diagram of $\mathbf{2}$ viewed down the $c$ axis showing the pseudohexagonal arrangement of fullerenes with $C_{3}$-symmetric helical arrangement of $\mathbf{2}$ at the vertices of the pseudohexagon.

with excess MeLi, followed by hydrolysis. ${ }^{12,13}$ Furthermore, treatment of the dodecaadduct $\mathrm{C}_{60} \mathrm{Me}_{5} \mathrm{HPh}_{5} \mathrm{H}$ with $\mathrm{KH}$ followed by exposure to molecular oxygen afforded the penta-oxygenated product $\mathrm{C}_{60} \mathrm{Me}_{5} \mathrm{O}_{2}(\mathrm{OH}) \mathrm{Ph}_{5} \mathrm{O}(\mathrm{OH})$ as confirmed by an X-ray structure. ${ }^{14}$

Red-colored cubic crystals of $\mathbf{2}$ suitable for single crystal $\mathrm{X}$-ray diffraction analysis were obtained by slow diffusion of cyclohexane into a THF solution of $\mathbf{2}$ containing also 5\% of trifluoroacetic acid, which was necessary to induce clean crystallization. The crystals belong to the hexagonal crystal system and the space group of $R \overline{3}$. ${ }^{15}$ The unit cell comprises nine pairs of molecules stacked in a head-to-head manner forming dimers related by a center of inversion (Figure 1).

The closest intermolecular contact between the two partners of a dimeric pair is $2.893 \AA$ for the $\mathrm{O} 1-\mathrm{C} 82^{\prime}$

(12) Al-Matar, H.; Hitchcock, P. B.; Avent, A. G.; Taylor, R. Chem. Commun. 2000, 1071-1072.

(13) Al-Matar, H.; Abdul-Sada, A. K.; Avent, A. G.; Fowler, P. W.; Hitchcock, P. B.; Rogers, K. M.; Taylor, R. J. Chem. Soc., Perkin Trans. 2 2002, 53-58.

(14) (a) Nakamura, E.; Tahara, K.; Matsuo, Y.; Sawamura, M. J. Am. Chem. Soc. 2003, 125, 2834-2835. (b) Matsuo, Y.; Tahara, K.; Sawamura, M.; Nakamura, E. J. Am. Chem. Soc. 2004, 126, 8725-8734.

(15) X-ray data for $\mathbf{2} \cdot\left(\mathbf{C}_{\mathbf{6}} \mathbf{H}_{12}\right)_{\mathbf{1 . 4}}$ : Red cube $\left(0.12 \times 0.12 \times 0.12 \mathrm{~mm}^{3}\right)$ from THF/cyclohexane. Space group $R \overline{3} ; a=46.5271(19) \AA ; \quad b=$ 46.5271(19) $\AA ; c=26.061(2) \AA ; V=48857.77(5) \AA^{3} ; Z=18 ; T=100(2)$ $\mathrm{K} ; N_{\text {ref }}=26874 ; R_{1}=0.0717 ; R_{\mathrm{W}}=0.1907$. 
distance. This distance is much smaller than the sum of the van der Waals radii for carbon and oxygen $(3.22 \AA)$. Another particular feature of this dimer is in the relative orientation of two TPA phenyl rings closest to the fullerenes. The phenyl rings $\mathrm{C} 13-\mathrm{C} 14-\mathrm{C} 15-\mathrm{C} 16-\mathrm{C} 17-\mathrm{C} 18$ and $\mathrm{C} 68-$ $\mathrm{C} 69-\mathrm{C} 70-\mathrm{C} 71-\mathrm{C} 72-\mathrm{C} 73$ are both tilted with a $17.43^{\circ}$ angle (centroid-centroid distance: $12.918 \AA$ ) and placed in a face-to-face manner as to embrace the adjacent fullerene moiety, acting as tweezers.

The pairs of tetraadduct epoxide 2 pack in the $a b$ plane of the unit cell in an extended deformed hexagonal geometry occupying the edges of a pseudohexagon (Figure 1b). The fullerene cores assemble themselves into $C_{3}$-symmetric helices at the vertices of the pseudohexagon. Centroidcentroid distances between these $\mathrm{C}_{60}$ cores are $10.132 \AA$, corresponding to carbon-carbon close contacts of $3.442 \AA$ (C115-C125). Most of the voids in this packing structure are occupied by the substituent phenyl rings and two located molecules of cyclohexane solvent per fullerene.

The mechanism involved in the transformation of $\mathbf{1}$ to $\mathbf{2}$ can be rationalized by the pathway in Figure 2. First, single electron transfer (SET) from the fullerenyl anion $\mathbf{1}^{-}$to molecular oxygen generates the superoxide anion and the corresponding fullerene cyclopentadienyl radical $\mathbf{1}^{\cdot}{ }^{11}$ Radical $\mathbf{1}{ }^{\circ}$ is trapped by another molecule of oxygen to give peroxyl radical $3^{\circ}$. Peroxyl radical $3^{\circ}$ subsequently undergoes cyclization with the nearest TPA arm to give the resonancestabilized spiro peroxide radical $4^{*}$.

The intermediate radical $\mathbf{4}^{*}$ is analogous to the wellestablished species formed in the quenching of peroxidic radicals by phenols like 2,6-di-tert-butyl-4-cresol (BHT). ${ }^{16}$ Spiro peroxide radical $4^{\circ}$ undergoes homolytic $\mathrm{C}-\mathrm{C}$ bond cleavage and ensuing rearomatization of the TPA group to form the resonance-stabilized radical $\mathbf{5}^{\circ}$. Several examples of rearrangement of alkoxy radical via spirocyclic intermediates into stabilized carbon radicals have been reported. ${ }^{17}$ Radical $5^{\cdot}$ undergoes epoxide formation to give $\mathbf{2}$ via $\mathrm{O}-\mathrm{O}$ bond fragmentation and intramolecular cyclization with release of the 4-(diphenyl-amino) phenoxy radical. The phenoxy radical may be ultimately oxidized to quinoid cation $\mathbf{6}$, although we have not be able to identify any TPA-derived molecular byproduct in this reaction.

In summary, adduct $\mathbf{1}$ dearylates surprisingly easily under basic aerobic conditions to give epoxide $\mathbf{2}$ in high yield. An

(16) (a) Pryor, W. A.; Gu, J. T.; Church, D. F. J. Org. Chem. 1985, 50, 185-189. (b) Ingold, K. U. Acc. Chem. Res. 1969, 2, 1-9.

(17) (a) Banks, J. T.; Scaiano, J. C. J. Phys. Chem. 1995, 99, 35273531. (b) Hartung, J.; Gottwald, T.; Špehar, K. Synthesis 2002, 11, 14691498.
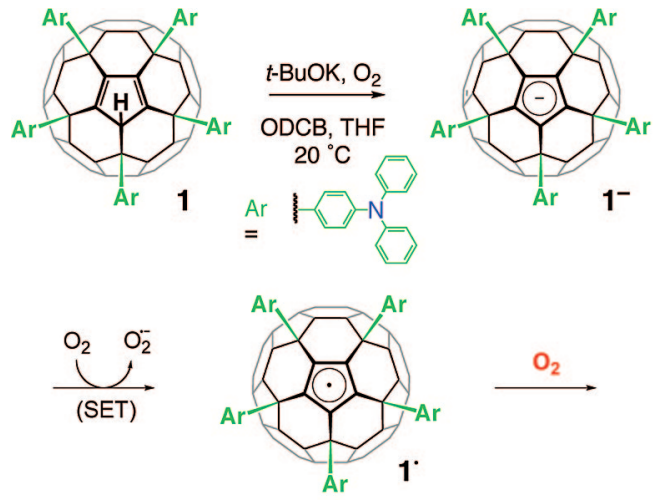

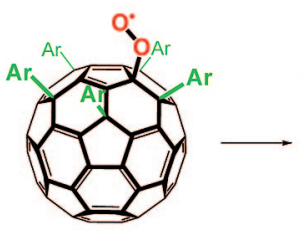

3.

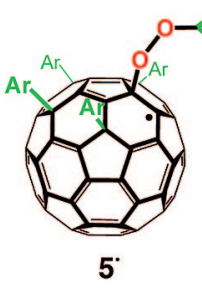

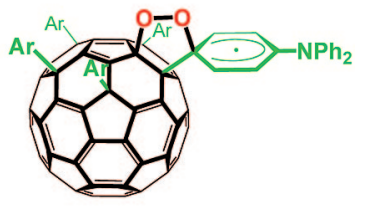

$4^{\cdot}$

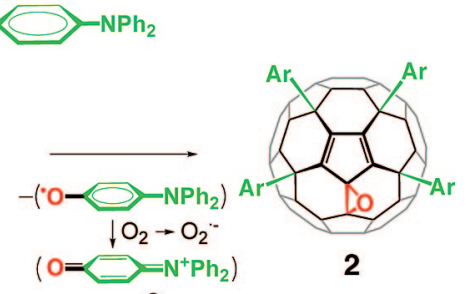

Figure 2. Proposed mechanism for the dearylation of pentaadduct $\mathbf{1}$ to tetraadduct $\mathbf{2}$.

$\mathrm{X}$-ray structure unambiguously shows that this compound bears four triphenylamine addends and an epoxide ring arranged around one pentagon of the fullerene. A mechanism explaining the loss of one triphenylamine arm and the subsequent formation of an epoxide has been proposed. We are exploring the scope of this reaction on related structures.

Acknowledgment. This work was supported by research and instrumentation grants NSF-CHE-0527015, NSF-CHE0617052 and ONR-N00014-04-1-0410 (YR), NSF-CHE9974928 (NMR), NSF-CHE-9871332 (X-ray).

Supporting Information Available: Experimental section, spectroscopic and crystallographic data for compounds $\mathbf{1}$ and 2. This material is available free of charge via the Internet at http://pubs.acs.org.

OL900224W 